Journal of Environmental Science and Sustainable Development

Volume 4

Issue 2 December

Article 4

$12-31-2021$

\title{
DO SOCIO-DEMOGRAPHIC FACTORS AND SOURCES OF INFORMATION RELATE TO CLIMATE CHANGE AWARENESS? EVIDENCE FROM AFROBAROMETER ROUND 7 DATA
}

\author{
Ayodeji P. Ifegbesan \\ Olabisi Onabanjo University, Ago-Iwoye, Ogun State, Nigeria, ifegbesan.ayodeji@oouagoiwoye.edu.ng \\ Razaq O. Azeez \\ Olabisi Onabanjo University, Ago-Iwoye, Ogun State, Nigeria, azeez.razaq@oouagoiwoye.edu.ng \\ Sesan Mabekoje \\ Olabisi Onabanjo University, Ago-Iwoye, Ogun State, Nigeria, mabekoje.sesan@oouagoiwoye.edu.ng
}

Follow this and additional works at: https://scholarhub.ui.ac.id/jessd

Part of the Life Sciences Commons, and the Social and Behavioral Sciences Commons

Recommended Citation

Ifegbesan, Ayodeji P.; Azeez, Razaq O.; and Mabekoje, Sesan (2021). DO SOCIO-DEMOGRAPHIC FACTORS AND SOURCES OF INFORMATION RELATE TO CLIMATE CHANGE AWARENESS? EVIDENCE FROM AFROBAROMETER ROUND 7 DATA. Journal of Environmental Science and Sustainable Development, 4(2), 222-247.

Available at: https://doi.org/10.7454/jessd.v4i2.1098

This Original Research Article is brought to you for free and open access by the School of Environmental Science at UI Scholars Hub. It has been accepted for inclusion in Journal of Environmental Science and Sustainable Development by an authorized editor of UI Scholars Hub. 


\title{
DO SOCIO-DEMOGRAPHIC FACTORS AND SOURCES OF INFORMATION RELATE TO CLIMATE CHANGE AWARENESS? EVIDENCE FROM AFROBAROMETER ROUND 7 DATA
}

\author{
Ayodeji P. Ifegbesan ${ }^{1 *}$, Razaq O. Azeez ${ }^{1}$, Sesan Mabekoje ${ }^{1}$ \\ ${ }^{1}$ Olabisi Onabanjo University, Ago-Iwoye, Ogun State, Nigeria \\ *Corresponding author: ifegbesan.ayodeji@oouagoiwoye.edu.ng \\ (Received: 25 November 2020; Accepted: 7 November 2021; Published: 30 December 2021)
}

\begin{abstract}
Climate change has been considered the most significant environmental catastrophe which is currently threatening human survival. Like the rest of other countries on the African continent, climate change in Nigeria has debilitating effects on both the people and the community due to vulnerability and poor coping capability of the people. Numerous studies related to the problem of rising temperatures in Africa are now being carried out and documented. However, only a little research evidence is available, particularly from Nigeria, regarding the way socio-demographic factors and sources of information are related to climate change awareness. The Afrobarometer Round 7 data for Nigeria was released in 2019 with a sample of 1600 drawn from the 36 states in the country through a clustered, stratified, multi-stage, random sample. The data were subjected to different statistical analyses of t-test, ANOVA, correlation, and regression. The study found that a majority of participants received information about climate change on the internet, social media, TV, and radio. Only a few of the participants obtained climate change-related information from the newspapers. The results showed significant differences in climate change awareness based on gender and place of respondents' residences. One-way ANOVA showed that significant differences exist in climate change awareness among educational and regional groups. However, no significant difference was found in the awareness of climate change among age groups. In contrast, a significant positive relationship among gender, place of residence, region, and awareness of climate change was observed. Internet news and climate change awareness were found to be negatively significantly related. Stepwise regression analysis showed that internet news was the most parsimonious set of climate change predictors. It is suggested that for a better understanding of climate change, government agencies and other stakeholders should use the internet and various social media platforms to disseminate information related to climate change. Subscription to social media platforms should be made cheap for the citizens for broader coverage which in turn engenders well-informed citizenry.
\end{abstract}

Keywords: Awareness; Climate change; Nigeria; Source of information; Sociodemographic. 


\section{Introduction}

There is an overwhelming consensus among environmentalists, conservationists, geographers, climatologists, and other interested advocates on the fact that climate change is a reality humanity now lives with. There are varying degrees of public concerns about climate change. The signals are clearer, and consequences are visibly stirring us in the face daily that no one should still be in doubt. In the past few decades, climate change has been recognized as a major hazard to the natural environment, public health, and food security. Human ingenuity and ever-increasing actions, especially those resulting from industrial development coupled with the alarming population increase, have upset the balance of the environment (IPCC, 2018; Lujala et al., 2015; Steynor \& Pasquini, 2019). These and many more concerns about effects of climate change on socio-economic landscape requires some level of awareness among the community members.

The term awareness can be simply and broadly defined as the state or quality of being aware of something. It means being knowledgeable, conscious, cognizant, and informed. With respect to climate change awareness, it is the consciousness of individual or group of the changes in the climate. Climate change awareness has been identified as a critical component in motivating the public to combat climate change as a global threat. Lack of awareness is a key barrier to climate change adaptation and environmental sustainability most especially in developing countries (Ghulam et al., 2019; Kuthe et al., 2020).

Climate change is a global phenomenon of climate transformation characterized by changes in the planet's normal climate (temperature, precipitation, and wind) driven primarily by human activity. According to National Aeronautics and Space Administration (NASA) (2019) climate change is "a broad range of global phenomena created predominantly by burning fossil fuels, which add heat-trapping gases to Earth's atmosphere. These phenomena include the increased temperature trends described by global warming, but also encompass changes such as sea-level rise, ice mass loss in Greenland, Antarctica, the Arctic and mountain glaciers worldwide; shifts in flower/plant blooming; and extreme weather events." (Youmatter, 2020). Succinctly, climate change refers to any observed variations in climate systems resulting from human activities, particularly those that interrupt the Earth's atmospheric equilibrium composition and eventually contribute to what is known as global warming. 
Global warming refers to a rise in the Earth's atmosphere and ocean temperatures caused by human activities such as burning wood, wood products, and solid waste, burning fossil fuels (natural gas, coal, and oil), and burning solid waste. This phenomenon is also caused by fossil fuels resulting from the burning of vegetation and deforestation, mining and agricultural operations, livestock breeding, and deforestation (IPCC, 2015; 2018). Recent research evidence estimated that global warming is likely to exceed $1.5^{\circ} \mathrm{C}$ in the coming decades precisely by 2030 , concluding that limiting warming to $1.5^{\circ} \mathrm{C}$ or even $2^{\circ} \mathrm{C}$ will be impossible to achieve unless fast, quick, and large-scale reductions in greenhouse gas emissions occur (Mora et al., 2018; IPCC, 2018; 2021). Uncontrolled greenhouse gas emissions are causing a slew of problems, including sea-level rise, hurricanes, fires, droughts, and floods.

Numerous studies related to the problem of rising temperatures in Africa are now being carried out and documented. The World Health Organisation (WHO) claimed that climate change is no longer a mere narrative. Instead, it has become a climate crisis that has emerged because there have been many health problems associated with it. The growing severity of extreme weather is one manifestation of climate change, which causes injury, sickness, and death in neonates due to heat stress, air pollution, and infectious diseases (Gennaro et al., 2017; Geruso \& Spears, 2018; Nsengiyumva et al., 2020; Steynor \& Pasquini, 2019; WHO, 2019).

Many scientists, social scientists, and environmental education scholars have carried out numerous studies on climate change, the causes, future effects, mitigation, and adaptation approaches (Frondel et al., 2017; Lujala et al., 2015; Rankoana, 2016). Climate change research on a variety of topics - including adaptation, experience, and perception, the influence of socio-demographic factors on climate change sensitivity, knowledge, and understanding are available in the literature (Odafivwotu, 2015; Opaluwa et al., 2020; Ricart et al., 2018). Human views, behavior, and practices regarding climate change are influenced by variables such as personal beliefs, societal values, experience, and socio-economic demographics (for instance, gender, age, occupation, educational attainment, and place of residence).

In a study conducted in three cities in Turkey, Korkmaz (2018) found nearly half of the respondents were knowledgeable about climate change. Demographic information on 
awareness of climate change disclosed females showed more concern about climate change than their male counterparts. Further, age and income were not determinants. Also, statistically significant differences were not found in climate change awareness based on age, class, income, and educational level. Using the 2007-2008 Gallup World data of 119 countries, Lee et al. (2015) studied the influence of perceived wellbeing, socio-demographic factors, beliefs, and geography on public risk perceptions, and climate change awareness. The study discovered that educational level was the most effective predictor of climate change awareness in all countries studied, that understanding anthropogenic sources was the most potent predictor of climate change risk perceptions in Europe and Latin America, and that perception of local temperature change was the most powerful predictor of climate change risk perceptions in most African and Asian countries studied. Haq and Ahmed's (2017) study in Bangladesh explored the socio-demographic dimension of perception of climate change. The result found differences in the perception of climate change across gender, marital status, religion, and age.

One of the variables of interest in the study is the source of information. There are two categories of information sources in the literature, namely social media and mass media. Examples of mass media are newspapers, television, radio, while social media include the Internet. The individual's level of awareness is a function of the source of information. The degree of information available to an individual on an issue will determine the level of awareness (Ajaero \& Anorue, 2018; Popoola et al., 2020). Thus, the dissemination of appropriate climate change information is a critical factor to effective adaptation. Literature evidence revealed that the primary sources of information on climate change and related issues have been always updated through radio, television, neighbors/friends, and newspapers.

Selormey et al. (2019) study showed that majority of the respondents were aware of the change in climate and their major sources of information were family members and radio. Exposure to news from any source is associated with substantially higher levels of awareness. Respondents who get news daily from the internet (74\%), social media (72\%), and newspapers (72\%) are substantially more likely to have heard of climate change than those who get daily news from television (65\%) and radio (64\%). Also, Nwabueze et al. (2019) 
observed that farmers in Zamfara state had a high level of awareness of climate change through information sources such as Radio, Television, and extension services.

González-Hernández et al. (2019) in their study of climate change mitigation and adaptation action in Nuevo Leon, Mexico, used data from 622 households. Ordinal regression analysis revealed financial self-efficacy and perceived knowledge had a significant impact on the degree of household-level action taken. Furthermore, perception and socio-demographic characteristics were found to influence the mitigation and adaptation actions of respondents. Ajuang et al. (2016) study was to find out how much people in Upper Nyakach Division, Kisumu County, Kenya, knew about climate change. According to the findings, 90.9 percent of respondents had seen changes in the overall climate. Climate change awareness differed widely across the 11 sub-locations. The findings revealed that respondents' awareness of climate change was influenced by the gender of the household head, their education level, and their age. Addisu et al. (2016) found educational level, age, wealth status, and agricultural extension services as important factors affecting climate change adaptation. Parameters such as marital status, farm size, income generations, and access to information have a significant correlation to farmers' perceptions regarding climate change.

Rahman et al. (2021) conducted a study in Lao People's Democratic Republic (Laos), and Thailand to ascertain the understanding, attitudes, and practices (KAP) about climate change and dengue fever among rural and urban communities and government officials. They discovered large differences in attitudes toward climate change and dengue fever among people of different ages, levels of education, and socioeconomic status in selected communities in the two countries. Participants' understanding of climate change and dengue was strongly related to their level of education and socioeconomic status in Lao households. Climate change and dengue fever attitudes and practices were found to be linked to educational level and internet use.

Ogunbode and Arnold (2014) in their research conducted in Nigeria compared the effects of knowledge, morality, and threat perception of climate change behavioral intention. The result showed that the model of threat perception is the greatest influence on behavioral intent. Ogunjinmi et al. (2016) conducted a study on the impact of social media on awareness level and concerns about climate change of staff of the Federal University of Technology, Akure, Nigeria. The report revealed that social media is a key source of 
information through which they learned about climate change. Social media was also found to affect their climate change awareness. Sanga and Elia (2020) explored socio-demographic factors of access to climate change information among tomato-growing farmers in Tanzania's Mvomero area using a mixed methods approach. The majority of farmers utilize radio as a source of climate change information, according to the data. Gender, marital status, age, education level, and income were also identified to be socio-demographic characteristics impacting access to climate change information. In a related study conducted in Osun State, Nigeria, Ogunbode et al. (2019) examined the level of climate change awareness and revealed that more than one-third of the respondents were no knowledge of climate change. Radio and Television were the major sources of information about climate change.

Nigeria is Africa's most populous and economically powerful country. By the end of the century, it is predicted to surpass China as the world's second most populated country, after India. In 2015, Nigeria was designated as the 17th largest greenhouse gas emitter in the world and the second-largest in Africa after South Africa. Rising temperatures, unpredictable rainfall, rising sea levels and flooding, droughts and desertification, land degradation, more frequent extreme weather events, and loss of biodiversity are the signs that Nigeria's climate is changing.

Rainfall duration and intensity have increased, resulting in huge runoffs and flooding in several parts of Nigeria (Akande et al., 2017; Haider, 2019). Undoubtedly, Nigerians are feeling the effects of climate change. The extreme heat has impacted millions of people without access to air conditioning or electricity, with fluctuations in rainfall also found to be a threat to Nigeria's rain-dependent agricultural sector. Seasons of drought and excessive flooding have impacted agricultural activity and resulted in the loss of shelter in Nigeria as a result of climate change. Floods displaced nearly 1.9 million Nigerians in 2019, according to the National Emergency Management Agency (Akande et al., 2017; Akuwudike et al., 2018; Haider, 2019)

The vast majority of the literature that provides evidence of climate change impacts and responses in Nigeria, however, focuses on the agricultural sector and individual farming communities in particular regions of the country. Although the situation of climate change has been recorded in Nigeria, large volumes of research have been conducted mostly on awareness, perception, mitigation, and adaptation to climate change (Akuwudike et al., 
2018; Ogunbode et al., 2019). These prior studies did not place specific emphasis on climate change awareness and its relationship to the source of information and socio-demographic factors. It can be noted that very little published literature existed on awareness of climate change and its relation to information sources in Nigeria. If stakeholders fail to consider the sources of information that may influence public awareness of climate change, as community members, researchers, and environmental educators, then it will be difficult to respond effectively to these issues. Thus, the need for more empirical evidence on the associations between climate change awareness and behavior, the source of information, and demographic factors are urgently needed.

This study examined the climate change awareness among Nigerians to: (1) deepen people's understanding of what drives climate change awareness, (2) make suggestions that could enhance information, communication, and education about climate change in the future. This study answers the following research questions to achieve those goals:

1. What is the level of climate change awareness among Nigerians?

2. Is there any significant difference in climate change awareness across sociodemographic characteristics of Nigerians?

3. What is the relationship between socio-demographic and sources of information and climate change awareness among Nigerians?

4. What factors influence climate change awareness among Nigerians?

To explain and determine why individuals differ on climate change, this study is hinged on the socio-psychological Theory of Planned Behaviour - TPB (Ajzen, 2011). The TPB, the theoretical framework for this study, postulated that human behavior is influenced by both intention and behavioral control (that is, motivation and ability). Based on the theory, the individual's intentions are formed by three basic components -(i) attitude, (ii) subjective norms, and (iii) perceived behavioral control. TPB is a behavioral model that is commonly used in comprehending how people's behavior can change. The TPB is effective in predicting knowledge, attitudes, and practices (KAP) in fields like healthcare practices, environmental behavior, sexual behavior (Macovei, 2015; Masud et al., 2016; Si et al., 2019). Drawing mainly from the TPB theory, this study conceptualizes a model to predict and understand how the chain of interactions among sources of information and socio-demographics on 
climate change awareness. The model (figure 1) explains and predicts climate change awareness as a function of the influences of sources of information and socio-demographic characteristics. These model postulates that climate change awareness is influenced by sociodemographic factors and the source of information.

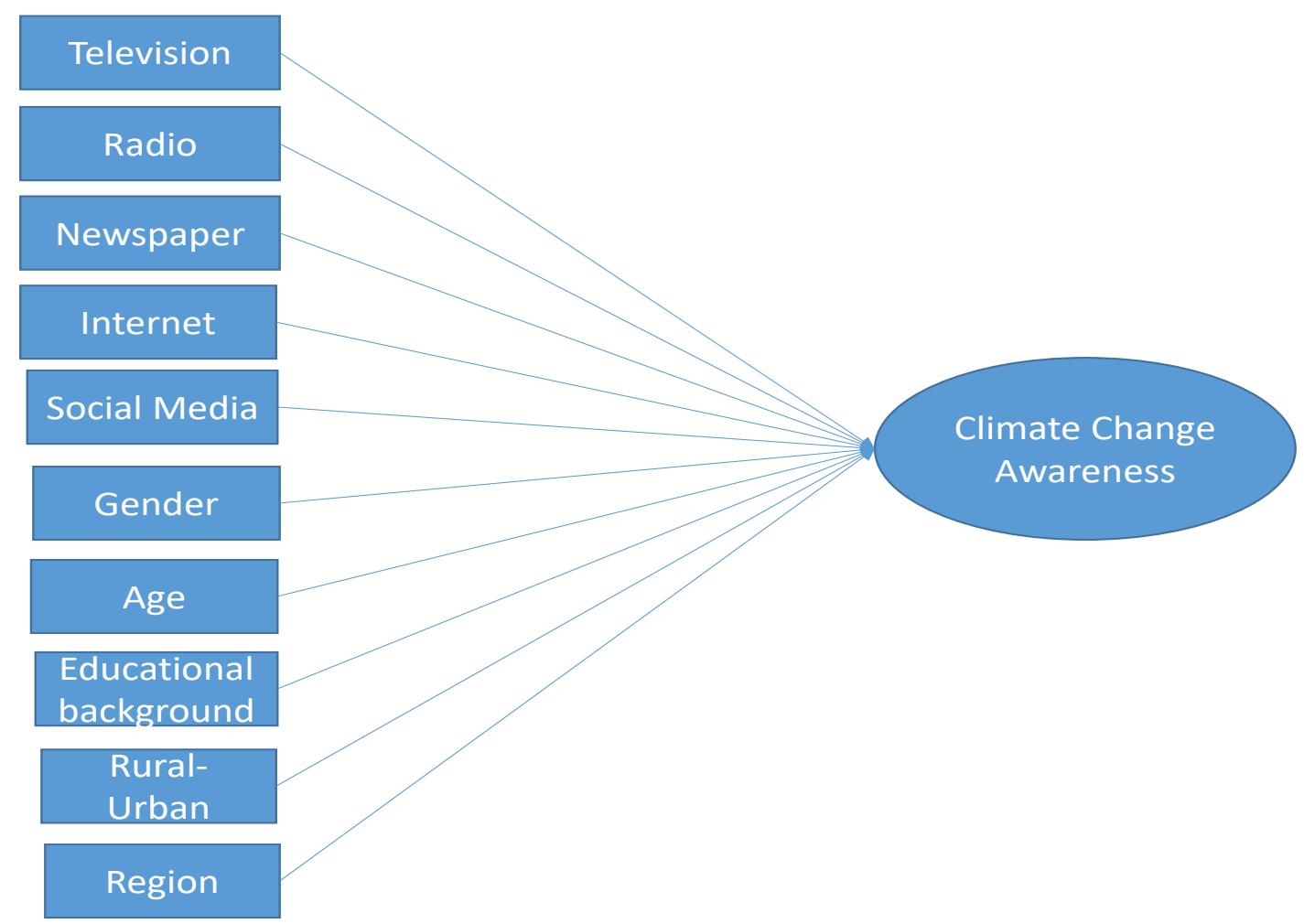

Figure 1. The conceptual model for the study

\section{Methods}

\subsection{Data source}

The study used the Afrobarometer Round 7 (2019) data for Nigeria. Afrobarometer is a panAfrican polling network that has conducted cross-national surveys of African countries on economic conditions, governance, democracy, and related issues.

Surveys were performed through face-to-face interviews with nationally representative populations in the language of the respondent's preference (Afrobarometer, 2017). The survey employed a clustered, stratified, multi-stage, area probability sample. The country was first stratified according to the main sub-national unit of government (state, province, region, etc.) and by urban or rural location. 
The samples were designed to generate a sample that is a representative cross-section of all citizens of voting age, namely citizens aged 18 and older in a given country. The sample excludes people living in institutionalized settings, such as students in dormitories, patients in hospitals, and persons in prisons or nursing homes. Furthermore, it excluded people in conflict or unsafe areas. The sample size of Round 7 for Nigeria was 1600 drawn from 36 states of the Federation and the Federal Capital Territory.

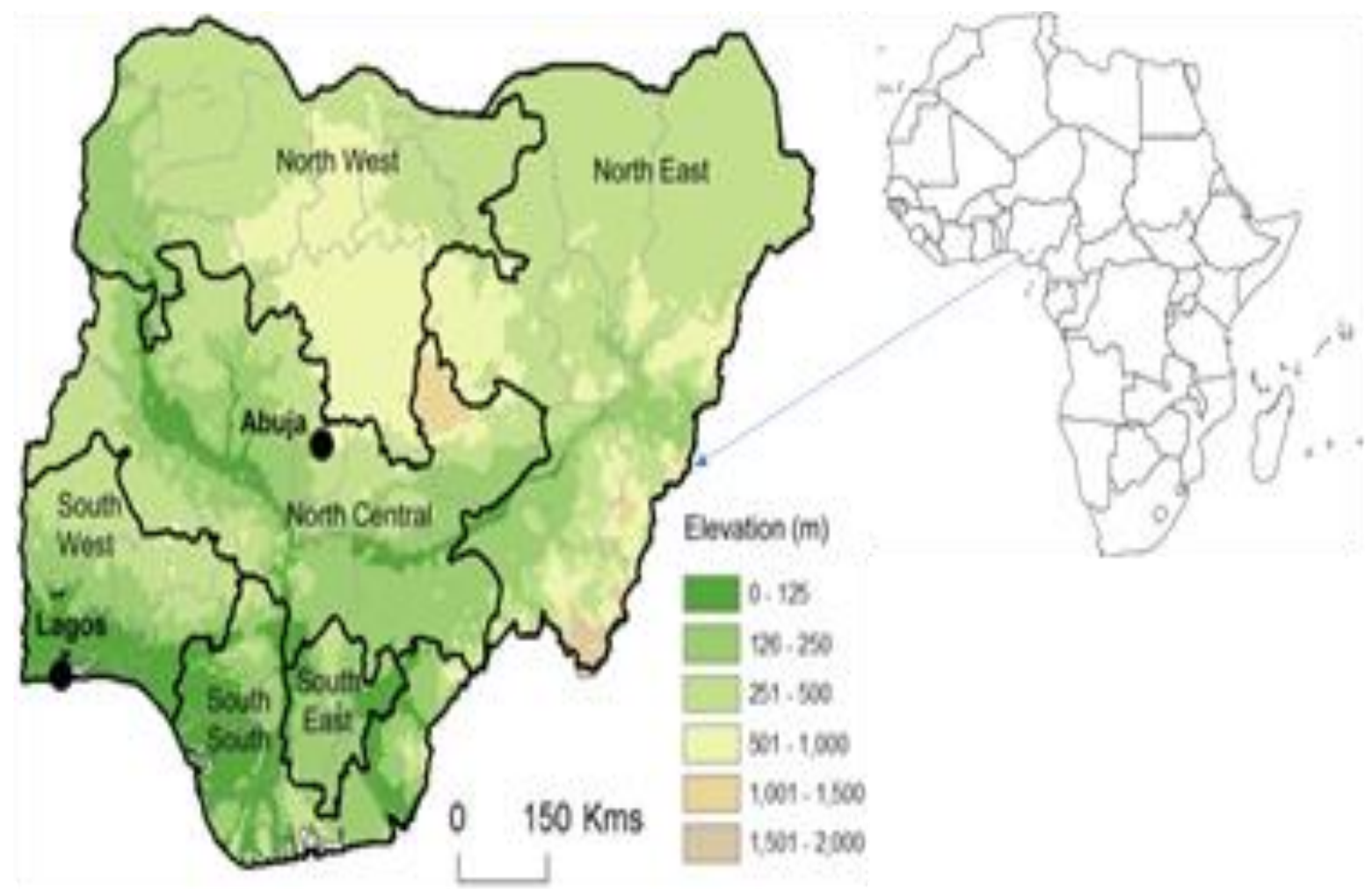

Figure 2. Map of Nigeria

Nigeria, with an estimated population of 206, 140 million (Statista, 2020) lies within the tropics between longitude 30 and 140 North, and latitudes 40 and 140 East comprising 36 states including the capital territory Abuja which is divided into six geopolitical regions (Figure 1). The landmass approximately covers an area of $923,768 \mathrm{~km}^{2}$. It measures about $1,200 \mathrm{~km}$ east-west and 1,050 km from north-south. The country's ecology comprises tropical forests to the south and dry savannahs to the far north. It has two seasons - the rainy season is between April and October, while the dry season is between November to March. 


\subsection{Variables}

Independent variables: Sources of information were measured through five items (Radio News, Television News, Newspapers, Internet news, and social media). Respondents' background characteristics, in this case, include gender, age, educational background, urban/rural, and region. The dependent variable, namely climate change awareness, was measured with eight (8) items designed on a 9-point Likert scale. These items were transformed by using the SPSS to create the climate change awareness variable. Some of the items are: 'Have you heard about climate change or haven't you had the chance to hear about this yet?', 'What does the phrase climate change mean to you?', Which of the following do you think is the main cause of climate change, or haven't you heard enough to say?', and 'Do you think climate change is making life in Nigeria better or worse, or haven't you heard?'

\subsection{Analysis}

A descriptive analysis was first conducted for demographics and items for the measure. The study then examined the difference in the dependent variable by respondents' demographic characteristics using a T-test and ANOVA. Pearson Product Moment Correlation was used to determine the relationships between demographics and sources of information on climate change awareness. The stepwise regression aims to identify the most cost-effective and best pool of information sources and socio-demographic variables for predicting climate change awareness. Meanwhile, the alpha level was set at .05

\section{Results and Discussions}

Table 1 provides a rundown of the respondents' demographic characteristics. The total sample size is 1600 which includes 801 females and 799 males. The respondents' average age is around 30 years. Nearly $44 \%$ had secondary education, $14.4 \%$ had no formal education, $13.6 \%$ had primary education, $13.1 \%$ had post-secondary education, and $15.1 \%$ had a university education. 
Table 1. Frequency and percentage distribution of respondents by socio-demographic characteristics

\begin{tabular}{|c|c|c|}
\hline Sex & Frequency & Percent \\
\hline Male & 801 & 50.1 \\
\hline Female & 799 & 49.9 \\
\hline \multicolumn{3}{|l|}{ Age } \\
\hline $18-25 y r s$ & 598 & 37.3 \\
\hline $26-35 \mathrm{yrs}$ & 501 & 31.3 \\
\hline $36-45 \mathrm{yrs}$ & 262 & 16.4 \\
\hline $46-55 \mathrm{yrs}$ & 132 & 8.2 \\
\hline $56-65 \mathrm{yrs}$ & 67 & 4.2 \\
\hline 66yrs above & 41 & 2.5 \\
\hline \multicolumn{3}{|c|}{ Educational background } \\
\hline No formal Education & 230 & 14.4 \\
\hline Primary education & 217 & 13.6 \\
\hline Secondary Education & 702 & 43.9 \\
\hline Post-Secondary & 209 & 13.1 \\
\hline University Education & 241 & 15.1 \\
\hline \multicolumn{3}{|l|}{ Place of Living } \\
\hline Urban & 696 & 43.5 \\
\hline Rural & 904 & 56.5 \\
\hline \multicolumn{3}{|l|}{ Region } \\
\hline South-West & 352 & 22.0 \\
\hline South-South & 258 & 16.2 \\
\hline South-East & 210 & 13.2 \\
\hline North-West & 367 & 22.9 \\
\hline North-East & 197 & 12.3 \\
\hline North-Central & 215 & 13.4 \\
\hline
\end{tabular}

In terms of place of residence, $56.5 \%$ were from the rural and $45.5 \%$ were in the urban area. The respondent had a more mixed profile of $13.4 \%$ North-Central, $12.3 \%$ North-east, South-west, and the North-west had $22.0 \%$ and $22.9 \%$ respective, $16.2 \%$ South-south, and $13.2 \%$ Southeast. Table 2 presents descriptive results of the source of information and awareness of climate change by participants. 
Table 2. Minimum and maximum scores, mean scores, standard deviation, skewness, and kurtosis. $(\mathrm{N}=1600)$

\begin{tabular}{|c|c|c|c|c|c|c|}
\hline & Minimum & Maximum & Mean & S D & $\begin{array}{l}\text { Skewness } \\
(\mathrm{SE}=.061)\end{array}$ & $\begin{array}{c}\text { Kurtosis } \\
(\mathrm{SE}=.122)\end{array}$ \\
\hline Radio news & 0 & 9 & 2.83 & 1.357 & -.950 & -.374 \\
\hline Television news & 0 & 9 & 2.00 & 1.652 & .193 & -.518 \\
\hline Newspaper news & 0 & 9 & .86 & 1.387 & 2.100 & 6.505 \\
\hline Internet news & 0 & 9 & 1.45 & 1.823 & .832 & -.078 \\
\hline Social media news & 0 & 9 & 1.47 & 1.845 & .859 & .065 \\
\hline $\begin{array}{l}\text { Climate conditions compared } \\
\text { to ten years ago }\end{array}$ & 0 & 9 & 2.72 & 1.763 & .911 & 2.523 \\
\hline Severity of droughts & 1 & 9 & 3.50 & 1.829 & 1.254 & 2.191 \\
\hline Severity of flooding & 1 & 9 & 3.64 & 1.694 & 1.094 & 2.284 \\
\hline Heard about climate change & 0 & 9 & .58 & .907 & 6.370 & 57.120 \\
\hline Meaning & 1 & 9 & 4.31 & 2.753 & -.077 & -1.855 \\
\hline Main cause & 1 & 9 & 4.36 & 2.731 & -.078 & -1.845 \\
\hline Affecting country & 1 & 9 & 5.13 & 2.111 & -.497 & -1.157 \\
\hline Needs to be stopped. & 0 & 9 & 4.19 & 3.006 & -.195 & -1.702 \\
\hline
\end{tabular}

Table 2 shows that radio news acts as the key source of information of climate change awareness with a mean score of 2.83 , followed by Television news, Internet news, and social media networks. The findings suggested that Television and Radio remain the main source of knowledge on climate change related problems among Nigerians.

The results of the t-test in Table 3 revealed a significant difference between male and female climate change awareness. This result implies that males and females significantly differ in their awareness of climate change. The mean scores indicate that the female respondents tend to have higher awareness than their male counterparts. Similarly, a significant difference in awareness of urban and rural climate change was also found. Rural respondents showed more awareness of climate change than their urban counterparts. This difference may be associated with the fact that most rural people mostly rely on natural resources (as fuel) for their livelihoods, which invariably had an impact on climate change so they feel the consequences more than urban residents. 
Table 3. Test of significant difference of climate change awareness by sex and place of residence.

\begin{tabular}{llllll}
\hline & $\mathrm{N}$ & Mean & S D & t & Sig. \\
\hline Male & 801 & 27.27 & 10.62 & -4.340 & .000 \\
Female & 799 & 29.59 & 10.78 & & \\
Urban & 696 & 27.57 & 10.59 & -2.798 & .005 \\
Rural & 904 & 29.08 & 10.85 & & \\
\hline
\end{tabular}

Analysis of variance (ANOVA) was conducted to decide whether there would be differences in awareness of climate change among Nigerians based on educational level, age, and regions (Table 4).

Table 4. Test of significant difference of awareness of climate change by educational level, region and age

\begin{tabular}{|c|c|c|c|c|}
\hline Educational background & $\mathrm{N}$ & Mean & S D & Statistics \\
\hline No formal Education & 230 & 31.9649 & 10.42962 & $\mathrm{~F}(4,1592)=15.450, \mathrm{p}<.001 \mathrm{~s}$ \\
\hline Primary Education & 216 & 31.5213 & 11.10631 & \\
\hline Secondary Education & 701 & 28.4420 & 10.37079 & \\
\hline Post-Secondary & 209 & 25.2273 & 10.43556 & \\
\hline University Education & 241 & 24.9922 & 10.35306 & \\
\hline Total & 1597 & 28.4223 & 10.76701 & \\
\hline \multicolumn{5}{|l|}{ Region } \\
\hline South-West & 352 & 28.8109 & 10.19243 & $F(5,1594)=15.617, p<.001 s$ \\
\hline South-South & 258 & 26.9517 & 10.31516 & \\
\hline South-East & 210 & 26.2904 & 10.12060 & \\
\hline North-West & 367 & 32.2418 & 10.67887 & \\
\hline North-East & 197 & 25.5222 & 10.35732 & \\
\hline North-Central & 215 & 27.8324 & 11.55095 & \\
\hline Total & 1600 & 28.4299 & 10.76455 & \\
\hline \multicolumn{5}{|l|}{ Age } \\
\hline $18-25 y r s$ & 596 & 29.5704 & 10.87421 & $\mathrm{~F}(5,1595)=3.257, \mathrm{p}<.006 \mathrm{~s}$ \\
\hline $26-35 y r s$ & 501 & 28.0711 & 10.75090 & \\
\hline $36-45 y r s$ & 262 & 27.7342 & 10.19797 & \\
\hline $46-55 \mathrm{yrs}$ & 132 & 26.8375 & 10.68368 & \\
\hline $56-65 y r s$ & 67 & 25.8093 & 10.56445 & \\
\hline
\end{tabular}




\begin{tabular}{lrlll}
\hline Educational background & N & Mean & S D & Statistics \\
\hline 66yrs above & 41 & 29.1249 & 10.55120 & \\
Total & 1599 & 28.4052 & 10.72619 & \\
\hline
\end{tabular}

It is not surprising to observe the differences that exist in climate change awareness among educational and regional groups. The findings indicate that the higher the educational qualification, the less the knowledge of climate changes. In contrast to other educational qualifications, those with tertiary education were more likely to be aware of climate change. Education is related to the acquisition of climate change awareness. There is no significant difference in the age group's awareness of climate change.

In this research, the post hoc analysis was conducted using the Turkey HSD to determine where the difference existed among the group. The results in Table 5 revealed that the three subsets were extracted for climate change awareness by region. Participants from North-East, South-East, South-South, and North-Central had a similar level of awareness and fell into a subset, whereas participants from South-East, South-South, North-Central, and South-West had a similar level of awareness of climate change. Participants from North-West had the highest level of awareness of climate change. Results also showed three subsets for climate change awareness by educational background. Participants with University education and those with post-secondary education had the least level of climate change awareness with a similar mean score while those with secondary education followed in the second subset. However, participants with primary and those without formal education had the highest level of climate change awareness and fell in the same subset.

Table 5. Summary of the Turkey multiple range comparisons of the mean scores on climate change awareness.

\begin{tabular}{lllll}
\hline & & \multicolumn{3}{c}{ Subset for alpha =0.05 } \\
\cline { 3 - 5 } Region & $\mathrm{N}$ & 1 & 2 & 3 \\
\hline North-East & 196 & 25.5222 & \\
South-East & 210 & 26.2904 & 26.2904 & \\
South-South & 258 & 26.9517 & 26.9517 & 32.2418 \\
North-Central & 214 & 27.8324 & 27.8324 & 28.8109 \\
South-West & 352 & & &
\end{tabular}

DOI: https://doi.org/10.7454/jessd.v4i2.1098 


\begin{tabular}{|c|c|c|c|c|}
\hline \multirow[b]{2}{*}{ Region } & \multirow[b]{2}{*}{$\mathrm{N}$} & \multicolumn{3}{|c|}{ Subset for alpha $=0.05$} \\
\hline & & 1 & 2 & 3 \\
\hline Sig. & & .137 & .079 & 1.000 \\
\hline \multicolumn{5}{|c|}{$\begin{array}{l}\text { Means for groups in homogeneous subsets are displayed. } \\
\text { a. Uses Harmonic Mean Sample Size }=250.867 \text {. } \\
\text { b. The group sizes are unequal. The harmonic mean of the group sizes is used. Type I } \\
\text { error levels are not guaranteed. }\end{array}$} \\
\hline \multirow[b]{2}{*}{ Educational background } & & \multicolumn{3}{|c|}{ Subset for alpha $=0.05$} \\
\hline & $\mathrm{N}$ & 1 & 2 & 3 \\
\hline University Education & 241 & 24.9922 & & \\
\hline Post-Secondary & 209 & 25.2273 & & \\
\hline Secondary Education & 701 & & 28.4349 & \\
\hline Primary education & 217 & & & 31.5722 \\
\hline No formal Education & 230 & & & 31.9649 \\
\hline Sig. & & .999 & 1.000 & .993 \\
\hline
\end{tabular}

Means for groups in homogeneous subsets are displayed.

a. Uses Harmonic Mean Sample Size = 259.208.

b. The group sizes are unequal. The harmonic mean of the group sizes is used. Type I error levels are not guaranteed.

Bivariate correlation was computed to describe the relationship between the dependent and independent variables. The results obtained are presented in Table 6. A significant positive correlation was observed $(r=.97, \mathrm{p}<.01)$ between gender and climate change awareness, place of residence (urban/rural) $(r=.088, \mathrm{p}<.001)$ and climate change awareness. There was also a strong correlation between the region of the respondents $(r=.137, \mathrm{p}<.001)$. These findings show that the sources of information measures and climatic change awareness are negatively correlated. These results brought to enquiry the type and richness of content of the information on climate change available on the various sources. 
Table 6: Correlation between demographic, sources of information and climate change awareness of respondents

\begin{tabular}{|c|c|c|c|c|c|c|c|c|c|c|c|}
\hline & Gender & Age & Education & $\begin{array}{l}\text { Urban/ } \\
\text { Rural }\end{array}$ & Region & $\begin{array}{l}\text { Radio } \\
\text { news }\end{array}$ & $\begin{array}{l}\text { Television } \\
\text { news }\end{array}$ & $\begin{array}{l}\text { Newspaper } \\
\text { news }\end{array}$ & $\begin{array}{l}\text { Internet } \\
\text { news }\end{array}$ & $\begin{array}{l}\text { Social } \\
\text { media } \\
\text { news }\end{array}$ & $\begin{array}{l}\text { Climate } \\
\text { change } \\
\text { Awareness }\end{array}$ \\
\hline Gender & 1 & $-.140^{* *}$ & $-.113^{* *}$ & .003 & -.001 & $-.127^{* *}$ & .012 & $-.147^{* *}$ & $-.107^{* *}$ & $-.082^{* *}$ & $.097^{* *}$ \\
\hline Age & & 1 & $-.146^{* *}$ & .037 & $-.053^{*}$ & $.053^{*}$ & -.024 & -.006 & $-.225^{* *}$ & $-.245^{* *}$ & $-.069^{* *}$ \\
\hline Education & & & 1 & $-.301^{* *}$ & $-.162^{* *}$ & $.169^{* *}$ & $.426^{* *}$ & $.298^{* *}$ & $.482^{* *}$ & $.458^{* *}$ & $-.241^{* *}$ \\
\hline Urban/Rural & & & & 1 & $.303^{* *}$ & $-.081^{* *}$ & $-.310^{* *}$ & $-.147^{* *}$ & $-.256^{* *}$ & $-.272^{* *}$ & $.088^{* *}$ \\
\hline Regions & & & & & 1 & $-.109^{* *}$ & $-.251^{* *}$ & $-.051^{*}$ & $-.097^{* *}$ & $-.129^{* *}$ & .011 \\
\hline Radio news & & & & & & 1 & $.252^{* *}$ & $.213^{* *}$ & $.149^{* *}$ & $.118^{* *}$ & $-.129^{* *}$ \\
\hline $\begin{array}{l}\text { Television } \\
\text { news }\end{array}$ & & & & & & & 1 & $.419^{* *}$ & $.445^{* *}$ & $.433^{* *}$ & $-.217^{* *}$ \\
\hline $\begin{array}{l}\text { Newspaper } \\
\text { news }\end{array}$ & & & & & & & & 1 & $.527^{* *}$ & $.476^{* *}$ & $-.199^{* *}$ \\
\hline $\begin{array}{l}\text { Internet } \\
\text { news }\end{array}$ & & & & & & & & & 1 & $.877^{* *}$ & $-.246^{* *}$ \\
\hline $\begin{array}{l}\text { Social } \\
\text { media news }\end{array}$ & & & & & & & & & & 1 & $-.229^{* *}$ \\
\hline Awareness & & & & & & & & & & & 1 \\
\hline
\end{tabular}

**. significant at $\mathrm{p}<.01$. *. significant at $\mathrm{p}<.05$ 
A stepwise linear regression model was conducted. The results of the stepwise regression analysis for all respondents which are shown in Table 7 indicate that the most parsimonious set of predictors of climate change awareness internet news.

Table 7. Stepwise regression analysis of thirteen predictor variables used to predict climate change awareness of respondents $(\mathrm{N}=1600)$

\begin{tabular}{|c|c|c|c|c|c|c|c|c|}
\hline \multirow[b]{2}{*}{ Step } & & \multicolumn{2}{|c|}{$\begin{array}{c}\text { Unstandardized } \\
\text { Coefficients }\end{array}$} & $\begin{array}{l}\text { Standardized } \\
\text { Coefficients }\end{array}$ & \multirow[t]{2}{*}{$\mathrm{t}$} & \multirow[t]{2}{*}{ Sig. } & \multicolumn{2}{|c|}{ Collinearity Statistics } \\
\hline & & $\mathrm{B}$ & $\begin{array}{l}\text { Std. } \\
\text { Error }\end{array}$ & Beta & & & Tolerance & VIF \\
\hline \multirow[t]{2}{*}{1} & (Constant) & 30.568 & .334 & & 91.634 & .000 & & \\
\hline & Internet news & -1.470 & .143 & -.249 & -10.274 & .000 & 1.000 & 1.000 \\
\hline \multirow[t]{3}{*}{2} & (Constant) & 33.479 & .601 & & 55.699 & .000 & & \\
\hline & Internet news & -1.660 & .145 & -.281 & -11.418 & .000 & .949 & 1.054 \\
\hline & Age & -1.207 & .208 & -.143 & -5.796 & .000 & .949 & 1.054 \\
\hline \multirow[t]{4}{*}{3} & (Constant) & 36.847 & .875 & & 42.093 & .000 & & \\
\hline & Internet news & -1.261 & .163 & -.213 & -7.736 & .000 & .743 & 1.346 \\
\hline & Age & -1.254 & .207 & -.148 & -6.066 & .000 & .947 & 1.056 \\
\hline & $\begin{array}{l}\text { Educational } \\
\text { background }\end{array}$ & -1.278 & .243 & -.143 & -5.255 & .000 & .766 & 1.305 \\
\hline \multirow[t]{5}{*}{4} & (Constant) & 36.922 & .874 & & 42.253 & .000 & & \\
\hline & Internet news & -1.107 & .171 & -.187 & -6.459 & .000 & 669 & 1.495 \\
\hline & Age & -1.193 & .207 & -.141 & -5.754 & .000 & .937 & 1.067 \\
\hline & $\begin{array}{l}\text { Educational } \\
\text { background }\end{array}$ & -1.081 & .252 & -.121 & -4.282 & .000 & .708 & 1.412 \\
\hline & Television news & -.513 & .180 & -.079 & -2.843 & .005 & .735 & 1.360 \\
\hline \multirow[t]{6}{*}{5} & (Constant) & 34.646 & 1.285 & & 26.953 & .000 & & \\
\hline & Internet news & -1.056 & .172 & -.179 & -6.128 & .000 & .659 & 1.517 \\
\hline & Age & -1.100 & .211 & -.130 & -5.221 & .000 & .906 & 1.104 \\
\hline & $\begin{array}{l}\text { Educational } \\
\text { background }\end{array}$ & -1.016 & .254 & -.113 & -4.007 & .000 & .700 & 1.428 \\
\hline & Television news & -.561 & .181 & -.086 & -3.095 & .002 & .726 & 1.377 \\
\hline & Gender & 1.266 & .525 & .059 & 2.411 & .016 & .943 & 1.061 \\
\hline \multirow[t]{4}{*}{6} & (Constant) & 35.682 & 1.379 & & 25.869 & .000 & & \\
\hline & Internet news & -1.049 & .172 & -.178 & -6.092 & .000 & .659 & 1.518 \\
\hline & Age & -1.075 & .211 & -.127 & -5.102 & .000 & .903 & 1.108 \\
\hline & $\begin{array}{l}\text { Educational } \\
\text { background }\end{array}$ & -.988 & .254 & -.110 & -3.897 & .000 & .698 & 1.432 \\
\hline
\end{tabular}




\begin{tabular}{|c|c|c|c|c|c|c|c|c|}
\hline \multirow{3}{*}{ Step } & & \multicolumn{2}{|c|}{$\begin{array}{c}\text { Unstandardized } \\
\text { Coefficients }\end{array}$} & $\begin{array}{l}\text { Standardized } \\
\text { Coefficients }\end{array}$ & \multirow[t]{2}{*}{$\mathrm{t}$} & \multirow[t]{2}{*}{ Sig. } & \multicolumn{2}{|c|}{ Collinearity Statistics } \\
\hline & & B & $\begin{array}{l}\text { Std. } \\
\text { Error }\end{array}$ & Beta & & & Tolerance & VIF \\
\hline & Television news & -.488 & .184 & -.075 & -2.647 & .008 & .700 & 1.429 \\
\hline \multirow{10}{*}{7} & Gender & 1.143 & .528 & .053 & 2.165 & .031 & .931 & 1.075 \\
\hline & Radio news & -.404 & .196 & -.051 & -2.057 & .040 & .914 & 1.094 \\
\hline & (Constant) & 33.538 & 1.718 & & 19.522 & .000 & & \\
\hline & Internet news & -1.043 & .172 & -.177 & -6.064 & .000 & .659 & 1.518 \\
\hline & Age & -1.065 & .211 & -.126 & -5.057 & .000 & .902 & 1.108 \\
\hline & $\begin{array}{l}\text { Educational } \\
\text { background }\end{array}$ & -.882 & .258 & -.099 & -3.412 & .001 & .671 & 1.490 \\
\hline & Television news & -.412 & .188 & -.063 & -2.192 & .029 & .673 & 1.485 \\
\hline & Gender & 1.218 & .529 & .057 & 2.302 & .021 & .926 & 1.079 \\
\hline & Radio news & -.431 & .197 & -.054 & -2.192 & .029 & .910 & 1.099 \\
\hline & Religion & 1.111 & .531 & .053 & 2.090 & .037 & .860 & 1.163 \\
\hline
\end{tabular}

\begin{tabular}{cccccccccc}
\hline & & \multicolumn{3}{c}{ Change Statistics } \\
Model & $\mathrm{R}$ & $\mathrm{R}^{2}$ & $\begin{array}{c}\text { Adjusted } \\
\mathrm{R}^{2}\end{array}$ & $\begin{array}{c}\text { Std. Error of } \\
\text { the Estimate }\end{array}$ & $\mathrm{R}^{2} \Delta$ & $\mathrm{F} \Delta$ & $\mathrm{df1}$ & $\mathrm{df2}$ & Sig. F $\Delta$ \\
\hline 1 & $.249^{\mathrm{a}}$ & .062 & .061 & 10.42900 & .062 & 105.552 & 1 & 1598 & .000 \\
2 & $.285^{\mathrm{b}}$ & .081 & .080 & 10.32423 & .019 & 33.598 & 1 & 1597 & .000 \\
3 & $.311^{\mathrm{c}}$ & .097 & .095 & 10.23927 & .016 & 27.611 & 1 & 1596 & .000 \\
4 & $.319^{\mathrm{d}}$ & .101 & .099 & 10.21663 & .005 & 8.080 & 1 & 1595 & .005 \\
5 & $.324^{\mathrm{e}}$ & .105 & .102 & 10.20126 & .003 & 5.812 & 1 & 1594 & .016 \\
6 & $.327^{\mathrm{f}}$ & .107 & .104 & 10.19093 & .002 & 4.232 & 1 & 1593 & .040 \\
7 & $.331^{\mathrm{g}}$ & .110 & .106 & 10.18017 & .002 & 4.368 & 1 & 1592 & .037 \\
\hline
\end{tabular}

Others included age, educational background, television news, gender, radio news, and the region. Together, these seven variables explained $11.0 \%$ of the variance in climate change awareness among Nigerians. The influence of these variables was not statistically significant $(\mathrm{F}=4.368$; sig. $\mathrm{F} \Delta=.037)$. The results obtained only showed five of the variables - internet news, age, educational level, television news, and gender significantly influenced the awareness regarding climate change among Nigerians. The variation that these variables described was 9.9 percent $\left(\mathrm{R}=.101\right.$, Adjusted $\left.\mathrm{R}^{2}=, 099\right)$. The other two variables - radio news and religion - had an insignificant impact. It should be noted that three of the five sources of 
information have been chosen from the seven predictor variables and have considerable impact.

The findings showed a high degree of sensitivity among respondents about climate change. The study found that most of the participants had awareness of the causes and effects of climate change. The finding is consistent with Selormey et al. (2019), who found that majority of the respondents used in their study showed a high level of global climate change awareness. The present findings contradict the findings of (Kuthe et al., 2019; Odafivwotu, 2015), which reported participants' low-level awareness of climate change.

According to the results, respondents' primary sources of information about climate change awareness were radio and television. The results corroborated Ogunbode et al. (2019) research which reported participants gathering information from television and radio news through which and they are educated and informed about climate change. The t-test result showed a significant difference between the effect of gender as well as a place of residence (urban and rural) on respondents' awareness of climate change. These results contradict Korkmaz's (2018) findings of no significant differences in climate change awareness regarding gender, age, income, and educational status.

The findings found the presence of a clear correlation or the effect between gender and place of residence on climate change awareness. These findings align with the results of previous studies that generally found a correlation between gender and knowledge of climate change (Chan et al., 2017; Odafivwotu, 2015). The study found out that respondents' level of climate change is a function of their sources of information. Findings, shown in Table 6, indicate a negative relationship between respondents' awareness of climate change and sources of information. There was also a positive correlation with the respondents' religions ( $\mathrm{r}$ $=.137, \mathrm{p}<.001$ ), which indicates that the origins of measures of knowledge and perception of climate change correlated but negative.

All the correlation was significant at $1 \%$, but not significant at 0.05 level. The negative association found in this study between educational level and climate change knowledge agrees with previous findings of scholars (Ogunbode et al., 2019; Sraku-Lartey et al., 2020). Sraku-Lartey et al. (2020) study in Ghana results indicated that perception of climate change is not influenced by level of education. Over the decades, there has been an increase in levels of awareness, knowledge, and comprehension of climate change (Capstick et al., 2015). 
Knight (2016) argued that this development in part to educational institutions' efforts to enlighten the public about the dangers of unabated climate change, and thus opined that a lack of formal education is associated with lower levels of climate concern. These findings are in line with the the import of Theory of Planned Behaviour (Ajzen, 2011), which states that action is based on an assessment of the behaviour's outcomes in terms of expected costs and benefits.

\section{Conclusion}

In this research, it was observed that most of the participants had a high degree of climate change understanding. The research finds that Nigerians' knowledge of climate change varies by socio-demographic factors, gender, educational background, age, place of residence, and region. Internet news, age, educational status, television, radio news, and gender are the key determinants of climate change awareness. These findings have added to the current literature and sparked fresh discussions about the role of information sources in climate change awareness. These results have implications for the design of climate change policies to raise knowledge and understanding of climate change. One of the consequences of these findings is that supporting media-supported efforts is particularly necessary to increase the level of awareness about adaptation to climate change.

Nigeria's government at the three levels (Federal, State, and Local) should promote increased knowledge and appreciation of the natural environment and of the risks posed by climate change and how to better manage. This can be realized by well-trained environmental health officers, agricultural extension workers from government agencies. Growing community understanding of the impacts of climate change makes it easier to reduce risks and strengthen adaptation. There is a need for government agencies, NGOs, the civil community association, and others concerned with issues related to the environment to make use of the internet and various other social media platforms to disseminate information related to climate change. To improve the local climate knowledge, community participation, and support climate action, climate-related themes and topics need to be integrated into school curricula at all levels of education. 
It is important to note that the data used in this study is limited to the Nigerian state. Future researchers in this area of study can look into the African data for possile comparison at sub-regional and country levels.

\section{Acknowledgement}

The authors wish to acknowledge and appreciate the Afrobarometer for providing the Round 7 data on Nigeria for this study. The authors also appreciate the anonymous reviewers who went through the first draft and made comments and suggestions that have improved the quality of the paper. The authors wish to confirm that there are no known conflicts of interest associated with this publication and there was no financial support for this study.

\section{Author Contribution}

The three authors participated in every stage of writing the paper. Ayodeji Ifegbesan, Razaq Azeez and Sesan Mabekoje conceptualised the idea. Ayodeji Ifegbesan sourced for and download the data, Ayodeji Ifegbesan, and Razaq Azeez did the analysis while Sesan Mabekoje confirmed, interpreted, and discussed the findings. Razaq Azeez and Ayodeji Ifegbesan wrote the first draft, the authors collectively contributed to the revision and the final manuscript.

\section{References}

Addisu S., Fissha, G., Gediff, B., \& Asmelash, Y. (2016). Perception and adaptation models of climate change by the rural people of lake Tana Sub-Basin Ethiopia. Environmental System Research. https://doi.org/10.1186/s40068-016-0059-0

Afrobarometer. (2017). Afrobarometer round 7 survey manual. https://afrobarometer.org/sites/default/files/survey_manuals/ab_r7_survey_manual_en1.pdf

Afrobarometer. (2019). Afrobarometer round 7. http://www.afrobarometer.org

Ajuang, C. O., Paul O. Abuom, P. O., Bosire, E. K., Dida, G. O., \& Anyona, D. N. (2016). Determinants of climate change awareness level in upper Nyakach Division, Kisumu County, Kenya. SpringerPlus, 5, 1015. https://doi.org/10.1186/s40064-016-2699-y 
Akande, A., Costa, A. C., Mateu, J., \& Henriques, R. (2017). Geospatial analysis of extreme weather events in Nigeria (1985-2015) Using self-organizing maps. Advances in Meteorology, 1-11. https://doi.org/10.1155/2017/8576150

Akuwudike, H. C., Igbokwe-Ibeto, C. J., \& Achilike, I. N. (2018). Imperative of climate change awareness on the sustainability of small and medium scale enterprises in Southeast, Nigeria. Review of Public Administration and management, 7(14), 89-98. https://www.ajol.info/index.php/ijdmr/article/view/197245

Ajaero, I., \& Anorue, L. (2018). Newspaper framing and climate change mitigation in Nigeria and Ghana. African Population Studies, 32(2), 4228-4238. https://doi.org/10.11564/32-2-1195

Ajzen, I. (2011). The theory of planned behaviour: Reactions and reflections. Psychology \& health, 26(9), 1113-1127. https://doi.org/10.1080/08870446.2011.613995

Capstick, S., Whitmarsh, L., Poortinga, W., Pidgeon, N., \& Upham, P. (2015). International trends in public perceptions of climate change over the past quarter century. WIREs Climate Change, 6, 35-61. https://doi.org/10.1002/wcc.321

Chan, E.Y. Y., Wang, S. S., Ho, J. Y., Huang, Z., Liu, S., \& Guo, C. (2017). Sociodemographic predictors of health and environmental co-benefit behaviours for climate change mitigation in urban China. PLoS ONE, 12(11), e0188661. https://doi.org/10.1371/journal.pone.0188661

Frondel, M., Simora, M., \& Sommer, S. (2017). Risk perception of climate change: Empirical evidence for Germany. Ecological Economics, 137, 173-183. https://doi.org/10.1016/j.ecolecon.2017.02.019

Gennaro, S., O’Connor, C., \& Marx, M. (2017). Global health of babies and children. MCN American Journal Maternal Child Nursing, 42(3), 132-138. https://doi.org/10.1097/NMC.0000000000000322

Geruso, M., \& Spears, D. (2018). Heat, Humidity, and Infant Mortality in the Developing World. NBER Working Papers 24870, National Bureau of Economic Research, Inc.

Ghulam M., Abd Latif, I., Bashir, M. K., Shamsudin, M. N., \& Wan Mohamed, N. W. D. (2019). Determinants of farmers' awareness of climate change. Applied Environmental Education \& Communication, 18(3), 219-233. https://doi.org/10.1080/1533015X.2018.1454358 
González-Hernández, D. L., Meijles, E. W., \& Vanclay, F. (2019). Factors that influence climate change Mitigation and Adaptation Action: A Household Study in the Nuevo Leon Region, Mexico. Climate, 7, 74. https://doi.org/10.3390/cli7060074

Haider, H. (2019). Climate change in Nigeria: Impacts and responses. K4D Helpdesk Report 675. Brighton, UK: Institute of Development Studies

Haq, S. A., \& Ahmed, K. J. (2017). Does the perception of climate change vary with the socio-demographic dimensions? A study on vulnerable populations in Bangladesh. Nat. Hazards 85, 1759-1785. https://doi.org/10.1007/s11069-016-2664-7

Intergovernmental Panel on Climate Change (IPCC). (2015). Climate Change 2014: Synthesis Report. Contribution of Working Groups I, II and III to the Fifth Assessment Report of the Intergovernmental Panel on Climate Change [Core Writing Team, R.K. Pachauri and L.A. Meyer (eds.)]. IPCC, Geneva, Switzerland. http://www.ipcc.ch.

Intergovernmental Panel on Climate Change (IPCC). (2018). Global warming of $1.5^{\circ} \mathrm{C}$. http://www.ipcc.ch/report/sr15/

Intergovernmental Panel on Climate Change (IPCC). (2021). IPCC Working Group I report, Climate Change 2021: the Physical Science Basis. https://www.ipcc.ch/2021/08/09/ar6-wg1-20210809-pr/

Knight, K. W. (2016). Public awareness and perception of climate change: A quantitative cross-national study. Environmental Sociology, 2(1), 101-113 https://doi.org/10.1080/23251042.2015.1128055

Korkmaz, M. (2018). Public awareness and perceptions of climate change: Differences in concern about climate change in the West Mediterranean region of Turkey. Applied Ecology and Environmental Research, 16(4), 4039-4050. https://dx.doi.org/10.15666/aeer/1604_40394050

Kuthe, A., Keller, L., Körfgen, A., Stötter, H., Oberrauch, A., \& Höferl, K-M. (2019). How many young generations are there? - A typology of teenagers' climate change awareness in Germany and Austria. The Journal of Environmental Education, 50(3), 172-182. https://doi.org/10.1080/00958964.2019.1598927 
Kuthe, A., Körfgen, A., Stötter, J., \& Keller, L. (2020). Strengthening their climate change literacy: A case study addressing the weaknesses in young people's climate change awareness. Applied Environmental Education \& Communication, 19(4), 375-388 https://doi.org/10.1080/1533015X.2019.1597661

Lee, T. M., Markowitz, E. M., Howe, P. D., Ko, C.-Y., \& Leiserowitz, A. A. (2015). Predictors of public climate change awareness and risk perception around the world. Nature Climate Change, 5, 1014-1020. https://doi.org/10.1038/nclimate2728

Lujala, P., Lein, H., \& Rød, J. K. (2015). Climate change, natural hazards, and risk perception: The role of proximity and personal experience. Local Environment, 20(4), 489-509. https://doi.org/10.1080/13549839.2014.887666

Macovei, O. I. (2015). Applying the theory of planned behaviour in predicting proenvironmental behaviour: The case of energy conservation. Acta Universitatis Danubius Economica, 11(4), 15-32.

Masud, M. M., Al-Amin, A. Q., Junsheng, H., Ahmed, F., Yahaya, S. R., Akhtar, R., \& Banna, H. (2016). Climate change issue and theory of planned behaviour: relationship by empirical evidence. Journal of Cleaner Production, 113, 613-623. https://doi.org/10.1016/j.jclepro.2015.11.080

Mora, C., Spirandelli, D., \& Franklin, E. C. (2018). Broad threat to humanity from cumulative climate hazards intensified by greenhouse gas emissions. Nature Climate Change, 8, 1062-1071. https://doi.org/10.1038/s41558-018-0315-6

National Aeronautics and Space Administration (NASA). (2019). Global climate change. https://climate.nasa.gov/resources/global-warming-vs-climate-change/

Nsengiyumva, R., Mukarubayiza, M. R., Murekatete, C., \& Meharry, P. (2020). Climate change Associated with neonatal health risks: Rwandan nurses and midwives' awareness and perceptions. Rwanda Journal of Medicine and Health Sciences, 3(2), 261-272. https://doi.org/10.4314/rjmhs.v3i2.15

Nwabueze, C. C., Tsafe, A. G., Sayudi, S., Yusuf, Z., \& Ja'afar, Z. (2019). Awareness, access and utilization of Information on climate change by farmers in Zamfara State, Nigeria. Library Philosophy and Practice (ejournal), 20106, 1-10.

http://digitalcommons.unl.edu/libphilprac/2106 
Odafivwotu, O. (2015). Public perception of climate change in Yenagoa, Bayelsa State, Nigeria. Geography Journal, 2015. http://dx.doi.org/10.1155/2015/208154

Ogunbode, C., \& Arnold, K. (2014). Knowledge, morality and threat perception: A juxtaposition of internal influences on climate change related behavioural intentions in Nigeria. Human and Ecological Risk Assessment, 20(1), 242-262. https://doi.org/10.1080/10807039.2012.729141

Ogunbode, T. O., Ogungbile, P. O., Odekunle, D., \& Asifat, J. T. (2019). Climate change awareness and its determinants in a growing city in the southwestern Nigeria using Multivariate Analysis. Journal of Environmental Sustainability, 7(1), 15-27. https://scholarworks.rit.edu/jes/vol7/iss1/2

Ogunjinmi, A. A., Sunday, O. R., Ogunjinmi, K. O., \& Adekoya, O. E. (2016). Influence of social media on climate change knowledge and concerns. Nigerian Journal of Agriculture, Food and Environment, 12(4), 23-30.

Opaluwa, H. I., Opeyemi, G., \& Eleojo, M. J. (2020). Determinants of choice of climate change adaptation strategies among rural farming households in Lokoja local government area, Kogi State, Nigeria. Journal of Agribusiness and Rural Development, 3(57), 299-308. https://doi.org/10.17306/J.JARD.2020.01324

Popoola. O. O., Yusuf, S. F. G., \& Monde, N. (2020). Information sources and constraints to climate change adaptation amongst smallholder farmers in Amathole district municipality, Eastern Cape Province, South Africa. Sustainability, 12, 5846. https://doi.org/10.3390/su12145846

Rahman M. D. Overgaard, S., Hans J., Pientong, C., Mayxaye, M., Ekalaksananana T., Aromsereea, S., Phanthanawiboona, S., Zafarh, S., Shipinh, O., Pauli, R. E., Phommachanhe, S., Pongvongsaj, T., Vannavongk, N., \& Haquel, U. (2021). Knowledge, attitudes, and practices on climate change and dengue in Lao People's Democratic Republic and Thailand. Environmental Research, 193, 110509. https://doi.org/10.1016/j.envres.2020.110509

Rankoana, S. A. (2016). Perceptions of climate change and the potential for adaptation in a rural community in Limpopo Province, South Africa. Sustainability, 8, 672. https://doi.org/10.3390/su8080672 
Ricart, S., Olcina, J., \& Rico, A. M. (2018). Evaluating public attitudes and farmers' beliefs towards climate change adaptation: Awareness, perception and populism at European Level. Land, 8(4), 1-24. https://doi.org/10.3390/land8010004

Sanga, E. K., \& Elia, E. F. (2020). Socio-demographic determinants of access to climate change information among tomato growing farmers in Mvomero district, Tanzania. University of Dar es Salaam Library Journal, 15(2), 121-136. https://journals.udsm.ac.tz/index.php/lj/article/view/3991

Selormey, E. E., Dome, M. Z., Osse, L., \& Logan, C. (2019). Change ahead experience and awareness of climate change in Africa.

https://www.africaportal.org/publications/change-ahead-experience-and-awarenessclimate-change-africa/

Si, H., Shi, J. G., Tang, D., Wen, S., Miao, W., \& Duan, K. (2019). Application of the Theory of Planned Behavior in Environmental Science: A Comprehensive Bibliometric Analysis. International Journal of Environmental Research and Public Health, 6, 1-26. https://doi.org/10.3390/ijerph16152788

Sraku-Lartey, M., Buor, D., Osei-Wusu, A., \& Foli, E.G. (2020). Perceptions and knowledge on climate change in local communities in the Offinso Municipality, Ghana. Information Development, 36(1), 16-35. https://doi.org/10.1177/0266666918811391

Statista. (2020). Statista Country Report- Statistics and market data in Nigeria. https://www.statista.com/study/48473/nigeria/

Steynor, A., \& Pasquini, L. (2019). Informing climate services in Africa through climate change risk perceptions. Climate Services, 15. https://doi.org/10.1016/j.cliser.2019.100112

World Health Organization. (2019). Ten threats to global health in 2019 Emergencies. https://www.who.int/news-room/spotlight/ten-threats-to-global-health-in-2019

Youmatter. (2020). Climate Change: Meaning, definition, causes, examples and consequences. $\quad \mathrm{https}$ ://youmatter.world/en/definition/climate-change-meaningdefinition-causes-and-consequences/ 